\title{
Characterizing the risk factors for the long-term survival of the Avita bone-level dental implants
}

Seyed Amirhossein Emamian Shirazi

Sahand University of Technology

Hosseinali Ramezanpour

KFP-Dental

hashem yousefi ( $\square$ ha.yousefi144@gmail.com )

KFP-Dental https://orcid.org/0000-0002-5313-1990

\section{Research}

Keywords: Dental Implants, Risk Analysis, Probability, Severity, Residual Risk, Risk Evaluation, Risk Control

Posted Date: December 16th, 2019

DOI: https://doi.org/10.21203/rs.2.18770/v1

License: (c) (1) This work is licensed under a Creative Commons Attribution 4.0 International License. Read Full License 


\section{Abstract}

Background: Risk analysis file will never be closed in the technical documentation of the dental implants for the marketing purpose. In this paper the most common risk factors categorized as implant-related risks, surgeon-related risks, patient-related risks, and maintenance-related risks in the manufacturing process, application, the long term usage and the so-called survival rate of dental implants are studied.

Methods: The importance of any of the potential risk factors directly related to the product or the processes which are indirectly related to the product quality are assessed based on their severity and probability of occurrence. Proper measurement called as mitigations are considered to standardize the risks to the acceptable criteria.

Results: The equivalent risk assessment factors are compared in pre-mitigation and post-mitigation stages. The aim was to see whether the factor reduces to the acceptable or conditionally acceptable state for each risk or not.

Conclusion: Through this comprehensive study, the risk analysis file is completed however it can be even more complete, in the future, at this industry. In the further studies, discretizing the steps of severity or probability to finer steps, and ultimately converting them to a continuous form would be aimed.

\section{Background}

Even if there are comprehensive studies on the causes of the dental implant failure, there is still a considerable rate of failure [1-2]. Investigating in the contribution of the risk analysis in completing the technical documentation of the dental implant through the manufacturing process is still necessary. There are different factors that are threats for the health of patients when placing dental implants as a root treatment solution. In general, usage of a dental implant is just rational if the benefits overcome the consequences of risk factors. Ultimately, risk analysis helps to provide marketing surveillance. However it has been used a lot for the clinical trials as well [3-4].

Some researchers believe that there are only two main categories of patient-related and implant-related risk factors, which are generally accepted to contribute in the success rate of surgeries [1-2, 5]. However, some researchers considered one more aspect of surgeon-related factors which itself is categorized under the implant-related factors [2]. This is partly because some of the angulated abutments are machined by the surgeons or relevant laboratories from the pre-milled abutments. There is another aspect to this problem which is related to the maintenance phase. In the next section, these aspects of the study have been elaborated as the general causes of the failure, where all the factors from the implant design and manufacturing process, to properly placement, and from the post-surgery to long-term survival are covered [6].

Implant-related risks: Implant-related risks mainly originate from the implant design parameters such as dimensions, aspect-ratio (length/diameter), material properties, safety factor and material roughness [6]. 
In addition, the manufacturing process, packing, storage, and providing adequate information to prevent misuse are also important stages before the surgical process.

Surgeon-related risks: Parameters such as surgeon's measurement from the bone level thickness, soft tissue level thickness, and timing of the surgery stay under the surgeon-related risk factors. Some of the surgeon-related factors are dependent to surgeon decisions and observations such as being adjacent to other teeth or implants [6-9].

Patient-related risks: The third category is the patient-related risk factors, which is focused by some other researchers [8-10]. Patient-related risk factors cover a wide range of diseases' history in patient. In addition, the current condition of skin, soft tissue and bone, as well as bleeding, smoking, alcohol consumption, the presence of bacterial plaques, and soft tissue volume growth rate are constructive factors in the survival or the failure of dental implants [10-11].

Maintenance-related risks: The next category of the risks called as maintenance-related factors which are mainly focusing on the post-surgery care and maintenance issues. This category is mainly efficient with the corporation of the patients. Proper instruction and the role of patient is key for achieving higher survival rate from this stage. In this work, although the patient-related factors are more focused by the authors, there is almost no maintenance responsibility lying on the patient yet.

In this research the main aim is to fully study the risk factors related directly to the product quality or indirectly through the processes of manufacturing and using dental implants. In order to formulate the importance of each risk factor, and provide the best surgery strategy, every patient's technical file needs to be documented based on a comprehensive risk analysis [10]. Thus, the risk analysis from the peri-implant stage has been documented. A parameter called in the literature as Equivalent Risk Assessed (ERA) [3] or in this work as risk priority number (RPN) collected and calculated from the severity and probability of the risk factors and have been used largely in this research. And the importance of the risk analysis in technical documentation of the dental implants is highlighted. Finally, the risk factors are characterized, analyzed, and control of the hazardous situations studied in dental implant production.

\section{Results And Discussion}

In this study the authors are motivated to assess the risk of the failure at the dental implants for the marketing purpose. To complete the risk analysis mitigations have been implemented to reduce the probability or severity of different risk types. Different types of risks of the failure of the products, and also the procedures are investigated. In this section, the list of the detected risks has been provided within the Table 1. 
Table 1

List of the risk factors of the dental implant production.

\begin{tabular}{|c|c|c|c|c|c|}
\hline No & $\begin{array}{l}\text { Foreseeable } \\
\text { Sequence of } \\
\text { Events }\end{array}$ & Hazardous Situation & Harms & Severity & Probability \\
\hline 1 & $\begin{array}{l}\text { Out of tolerance } \\
\text { circularity, } \\
\text { cylindricity and } \\
\text { straightness of the } \\
\text { titanium bars }\end{array}$ & $\begin{array}{l}\text { Crashes on the } \\
\text { external area of } \\
\text { machined products }\end{array}$ & $\begin{array}{l}\text { Lower primary } \\
\text { stability }\end{array}$ & Minor & Occasional \\
\hline 2 & $\begin{array}{l}\text { Out of tolerance } \\
\text { circularity, } \\
\text { cylindricity and } \\
\text { straightness of the } \\
\text { titanium bars }\end{array}$ & $\begin{array}{l}\text { Failure in connection } \\
\text { zone of machined } \\
\text { product }\end{array}$ & $\begin{array}{l}\text { Loss of } \\
\text { prosthetic } \\
\text { component } \\
\text { (detachment) }\end{array}$ & Minor & Occasional \\
\hline 3 & $\begin{array}{l}\text { Low quality } \\
\text { titanium bars } \\
\text { based on } \\
\text { composition } \\
\text { criteria }\end{array}$ & $\begin{array}{l}\text { Low quality of } \\
\text { machined product } \\
\text { surface }\end{array}$ & $\begin{array}{l}\text { Lower primary } \\
\text { stability }\end{array}$ & Minor & Remote \\
\hline 4 & $\begin{array}{l}\text { Inappropriate room } \\
\text { temperature of the } \\
\text { CNC unit }\end{array}$ & $\begin{array}{l}\text { Lubricant oil } \\
\text { properties differ and } \\
\text { tools might be } \\
\text { overheated }\end{array}$ & $\begin{array}{l}\text { Reduced CNC } \\
\text { tools life and } \\
\text { lower machine } \\
\text { quality }\end{array}$ & Serious & Occasional \\
\hline 5 & $\begin{array}{l}\text { Oil contamination } \\
\text { from CNC }\end{array}$ & $\begin{array}{l}\text { Inappropriate } \\
\text { sandblasted surface } \\
\text { property }\end{array}$ & $\begin{array}{l}\text { Slowed } \\
\text { osseointegration }\end{array}$ & Serious & Improbable \\
\hline 6 & $\begin{array}{l}\text { Residual internal } \\
\text { filings from CNC }\end{array}$ & $\begin{array}{l}\text { Low fitting of } \\
\text { abutment }\end{array}$ & $\begin{array}{l}\text { Loss of } \\
\text { prosthetic } \\
\text { component } \\
\text { (detachment) }\end{array}$ & Minor & Remote \\
\hline 7 & $\begin{array}{l}\text { Inappropriate room } \\
\text { temperature in QC } \\
\text { lab }\end{array}$ & $\begin{array}{l}\text { Calibration of the } \\
\text { visual measuring } \\
\text { device is lost; lower } \\
\text { accuracy of the } \\
\text { measurements }\end{array}$ & $\begin{array}{l}\text { Dimensional QC } \\
\text { data is not } \\
\text { accurate }\end{array}$ & Serious & Remote \\
\hline 8 & $\begin{array}{l}\text { Operating the } \\
\text { sandblasting } \\
\text { device with } \\
\text { different setting } \\
\text { from designed } \\
\text { instruction }\end{array}$ & $\begin{array}{l}\text { Inadequate sand } \\
\text { level, low pressure of } \\
\text { nuzzles, improper } \\
\text { nozzles' angles }\end{array}$ & $\begin{array}{l}\text { Low surface } \\
\text { roughness and } \\
\text { reduced } \\
\text { osseointegration }\end{array}$ & Serious & Remote \\
\hline 9 & $\begin{array}{l}\text { Residual sands } \\
\text { between threads } \\
\text { from sandblasting }\end{array}$ & $\begin{array}{l}\text { Non biocompatible } \\
\text { implant }\end{array}$ & $\begin{array}{l}\text { Untreatable } \\
\text { local infection } \\
\text { and } \\
\text { explantation }\end{array}$ & Catastrophic & Probable \\
\hline
\end{tabular}




\begin{tabular}{|c|c|c|c|c|c|}
\hline No & $\begin{array}{l}\text { Foreseeable } \\
\text { Sequence of } \\
\text { Events }\end{array}$ & Hazardous Situation & Harms & Severity & Probability \\
\hline 10 & $\begin{array}{l}\text { Variation in the } \\
\text { process of } \\
\text { anodising and } \\
\text { colouring the } \\
\text { abutments }\end{array}$ & $\begin{array}{l}\text { Non biocompatible } \\
\text { prosthetic parts }\end{array}$ & $\begin{array}{l}\text { Irritation/ } \\
\text { Inflammation in } \\
\text { local (Self } \\
\text { Limited) }\end{array}$ & Minor & Remote \\
\hline 11 & $\begin{array}{l}\text { Residual micro- } \\
\text { particles on final } \\
\text { product }\end{array}$ & Infection & $\begin{array}{l}\text { Local Infection } \\
\text { Recoverable }\end{array}$ & Critical & Remote \\
\hline 12 & $\begin{array}{l}\text { Air particle amount } \\
\text { in clean room is } \\
\text { beyond the } \\
\text { standard level }\end{array}$ & $\begin{array}{l}\text { Particles in the pack } \\
\text { of final product is } \\
\text { above the prescribed } \\
\text { range which might } \\
\text { lower the quality of } \\
\text { sterilization process }\end{array}$ & $\begin{array}{l}\text { Local Infection } \\
\text { Recoverable }\end{array}$ & Critical & Remote \\
\hline 13 & $\begin{array}{l}\text { Product is not } \\
\text { completely } \\
\text { sterilized }\end{array}$ & $\begin{array}{l}\text { Using unsterile } \\
\text { implants leads to } \\
\text { local infection }\end{array}$ & $\begin{array}{l}\text { Untreatable } \\
\text { local infection } \\
\text { and } \\
\text { explantation }\end{array}$ & Catastrophic & Occasional \\
\hline 14 & $\begin{array}{l}\text { Expiry date is } \\
\text { passed in the } \\
\text { stocks and the } \\
\text { product is sold }\end{array}$ & $\begin{array}{l}\text { Using unsterile } \\
\text { implants leads to } \\
\text { local infection }\end{array}$ & $\begin{array}{l}\text { Untreatable } \\
\text { local infection } \\
\text { and } \\
\text { explantation }\end{array}$ & Catastrophic & Occasional \\
\hline 15 & $\begin{array}{l}\text { Packaging integrity } \\
\text { and the sterility is } \\
\text { lost during } \\
\text { transportation }\end{array}$ & $\begin{array}{l}\text { Using unsterile } \\
\text { implants }\end{array}$ & $\begin{array}{l}\text { Untreatable } \\
\text { local infection } \\
\text { and } \\
\text { explantation }\end{array}$ & Catastrophic & Remote \\
\hline 16 & $\begin{array}{l}\text { Label artwork } \\
\text { contains incorrect } \\
\text { information or non- } \\
\text { compliance } \\
\text { between label and } \\
\text { implant }\end{array}$ & $\begin{array}{l}\text { Inappropriate implant } \\
\text { insertion and sinus } \\
\text { and nerve damage if } \\
\text { longer implant is } \\
\text { used }\end{array}$ & $\begin{array}{l}\text { Bone Damage or } \\
\text { extensive burn } \\
\text { to mucous } \\
\text { membrane }\end{array}$ & Serious & Occasional \\
\hline 17 & $\begin{array}{l}\text { Product labelling } \\
\text { fades or is rubbed } \\
\text { off }\end{array}$ & $\begin{array}{l}\text { Wrong implant } \\
\text { selection }\end{array}$ & Bone Damage & Serious & Remote \\
\hline 18 & $\begin{array}{l}\text { The blister or } \\
\text { plump ring of the } \\
\text { door is not easily } \\
\text { opened }\end{array}$ & $\begin{array}{l}\text { not a hazard but just } \\
\text { a failure }\end{array}$ & Discomfort & Negligible & Remote \\
\hline 19 & $\begin{array}{l}\text { After opening the } \\
\text { main capsule pack } \\
\text { the implant drop } \\
\text { down in the surgery } \\
\text { tray }\end{array}$ & Sterility is lost & $\begin{array}{l}\text { Untreatable } \\
\text { local infection } \\
\text { and } \\
\text { explantation }\end{array}$ & Catastrophic & Improbable \\
\hline
\end{tabular}




\begin{tabular}{|c|c|c|c|c|c|}
\hline No & $\begin{array}{l}\text { Foreseeable } \\
\text { Sequence of } \\
\text { Events }\end{array}$ & Hazardous Situation & Harms & Severity & Probability \\
\hline 20 & $\begin{array}{l}\text { The user would not } \\
\text { follow the } \\
\text { instructions to } \\
\text { prevent foreseeable } \\
\text { misuse }\end{array}$ & $\begin{array}{l}\text { Unforeseeable } \\
\text { misuse }\end{array}$ & $\begin{array}{l}\text { Bone necrosis } \\
\text { leading to } \\
\text { implant Loss }\end{array}$ & Critical & Occasional \\
\hline 21 & $\begin{array}{l}\text { Using unsterilized } \\
\text { surgical kit }\end{array}$ & $\begin{array}{l}\text { might cause } \\
\text { temporary health } \\
\text { infection }\end{array}$ & $\begin{array}{l}\text { Irritation/ } \\
\text { Inflammation in } \\
\text { local (Self } \\
\text { Limited) }\end{array}$ & Minor & Remote \\
\hline 22 & $\begin{array}{l}\text { Incorrect drilling } \\
\text { sequence or } \\
\text { insertion technique }\end{array}$ & Low primary stability & Loss of implant & Serious & Remote \\
\hline 23 & $\begin{array}{l}\text { Incompatible final } \\
\text { drill versus implant } \\
\text { shape }\end{array}$ & $\begin{array}{l}\text { Gap in the interface } \\
\text { of bone-implant }\end{array}$ & $\begin{array}{l}\text { Insufficient } \\
\text { Primary Stability }\end{array}$ & Serious & Remote \\
\hline 24 & $\begin{array}{l}\text { Incompatible } \\
\text { torque wrench } \\
\text { versus implant }\end{array}$ & $\begin{array}{l}\text { Overheating in bone- } \\
\text { implant interface and } \\
\text { tissue necrosis }\end{array}$ & $\begin{array}{l}\text { Insufficient } \\
\text { secondary } \\
\text { stability }\end{array}$ & Catastrophic & Remote \\
\hline 25 & $\begin{array}{l}\text { Low fitting between } \\
\text { implant and } \\
\text { abutment gap }\end{array}$ & Loosening & $\begin{array}{l}\text { Loss of } \\
\text { prosthetic } \\
\text { component } \\
\text { (broken) }\end{array}$ & Serious & Improbable \\
\hline 26 & $\begin{array}{l}\text { Incompatible } \\
\text { connection } \\
\text { between implant } \\
\text { and abutment } \\
\text { (bigger implant) }\end{array}$ & $\begin{array}{l}\text { Gap in the interface } \\
\text { of abutment-implant }\end{array}$ & $\begin{array}{l}\text { Microorganism } \\
\text { infiltration into } \\
\text { gap and local } \\
\text { infection }\end{array}$ & Critical & Improbable \\
\hline 27 & $\begin{array}{l}\text { Incompatible } \\
\text { connection } \\
\text { between implant } \\
\text { and abutment }\end{array}$ & Useless abutment & Discomfort & Negligible & Improbable \\
\hline 28 & $\begin{array}{l}\text { Tightening the } \\
\text { abutment screw } \\
\text { with a torque below } \\
\text { the prescribed } \\
\text { range }\end{array}$ & Screw loosening & $\begin{array}{l}\text { Loss of } \\
\text { prosthetic } \\
\text { component } \\
\text { (detachment) }\end{array}$ & Serious & Improbable \\
\hline 29 & $\begin{array}{l}\text { Tightening the } \\
\text { abutment screw } \\
\text { with a torque } \\
\text { above the } \\
\text { prescribed range }\end{array}$ & Screw fracture & $\begin{array}{l}\text { Loss of } \\
\text { prosthetic } \\
\text { component } \\
\text { (broken) }\end{array}$ & Serious & Occasional \\
\hline
\end{tabular}




\begin{tabular}{|clllll|}
\hline No & $\begin{array}{l}\text { Foreseeable } \\
\text { Sequence of } \\
\text { Events }\end{array}$ & Hazardous Situation & Harms & Severity & Probability \\
\hline 30 & $\begin{array}{l}\text { Dropping } \\
\text { components in the } \\
\text { patient's mouth }\end{array}$ & $\begin{array}{l}\text { The component } \\
\text { might blind the air } \\
\text { pass }\end{array}$ & Asphyxiation & Catastrophic & Remote \\
\hline 31 & $\begin{array}{l}\text { Material } \\
\text { hypersensitivities } \\
\text { and allergies }\end{array}$ & $\begin{array}{l}\text { Osseointegration } \\
\text { fails }\end{array}$ & Loss of implant & Serious & Remote \\
\hline 32 & $\begin{array}{l}\text { Infection in patient } \\
\text { mouth because of } \\
\text { incorrect healing } \\
\text { technique }\end{array}$ & Infection & Delayed healing & Minor & Remote \\
\hline 33 & $\begin{array}{l}\text { Implanting while } \\
\text { poor bone quality }\end{array}$ & $\begin{array}{l}\text { Osseointegration } \\
\text { fails }\end{array}$ & $\begin{array}{l}\text { Insufficient } \\
\text { primary and } \\
\text { secondary } \\
\text { stability }\end{array}$ & Critical & Occasional \\
\hline
\end{tabular}

\section{Proposed Mitigations}

In order to control the risks number 1,2, and 3, there are two different solutions. The first one is the process control and the other one is QC (raw material QC and in-line QC). The former includes prevention of inaccurate purchase based on designed procedure for purchases. There should be a rating list for the suppliers based on the votes of QC supervisor, financial director and commercial manager. Then the commercial manager would be allowed to place an order from the qualified and well-known sources. To reduce the probability of occurrence of the mentioned risks, two categories of QC parameters are designed, the first category measures and controls the dimensions based on the drawing checklist, and the second category visually control the surface.

There are two mitigations to control the risk number 4 related to the CNC lubricant oil failure in cooling the tools. The first one is the process control to prevent high variation of temperature which reduces the probability of occurrence of hazardous situations. Another useful mitigation would be to have tighter QC on products and also CNC tools, which prevents the use of unqualified products and notifies the operator to change the tools which reduces the severity of this hazard.

Similar to the importance of controlling the CNC unit temperature, since the accuracy of the visual measuring device is highly dependent on the temperature, the mitigation for risk number 7 should control the process. It means that in every time usage of the device the room temperature should be recorded in the QC form to validate the measured dimensions. Also, for risks numbers of 8 and 10 the best mitigation is to often validate and routinely control the process.

For risks numbers $5,6,9$, and 11 monitoring the process have been proposed together with in-line QC. In manufacturing line there are QC stations after washing/drying, sandblasting and before packaging the final product. All these stations are based on visual control by use of microscopes. On the other hand, 
since the sterility of packed product is very important because of the high severity of related harm, this risk is controlled by process control and also random quality control with a safety factor of 1.4 over the international standards. For instance, based on ISO 11137-1 the maximum interval of time between determinations of bioburden for our product shall be three months while every two months check have been proposed. However, some QC tests require expensive devices, so these kinds of tests are outsourced. For example, residual sands between threads are identified in SEM test. Thus, in addition to QC and PC that reduce the probability of occurrence, the severity of harm should have been lowered. This way Al2O3 sand is prescribed to increase the biocompatibility.

Focusing on the process control beside in-line quality control is valuable and in some situations PC is easier than QC. Since counting the particles in the package of final product is hard and time consuming, process control in clean-room is proposed instead of quality control of packaging. This mitigation for risk number 12 reduces both severity and probability since by controlling the process the probability of occurrence is reduced, and by setting a safety factor for accepted amount of particles in the air, the sterilization is with a better quality that reduces the infection severity.

Another group of risks are related to labelling and information supplied for the user (risks $16 \& 17$ ). Controlling the risks related to labelling is much easier than manufacturing risks. Color coding of packages' door and information supplied to the user is proposed through two labels, one of them on the backside of the cartoon, and the other one inside the blistering pack.

As previously emphasized, regarding the importance of sterility about the risk numbers 11 and 12, there are critical harms behind unsterile product. Therefore, double seal packaging with blister and sealing door was proposed to reduce the probability of loss of sterility during transportation (risk number 15). In addition, the sterility is assured for a definite time, which itself needs an expiry date for each product. To control the risk number 14 , the available stocks are systematically controlled in a detection and traceability process. This means that registering the batch number of expired products for invoicing is not allowed in the designed software. But, it is possible that the expiry date pass while the user stores the implant.

For risk number 24, an adjustable torque wrench that slips when the preset torque is reached out is proposed. Thus, no extra torque will be applied to the implant.

Grabbing the implant from capsule pack is prescribed to be done initially by driver with hand, and then tightening it with hand piece or torque wrench. Therefore, there is a risk of dropping implant or other components in the patient's mouth. To reduce the probability of this risk, a driver with high gripping force has been designed.

In addition, the risks numbers of $20,22,28,29$, and 30 would be controlled by specific design of the surgical kit. The kit is color coded and the color-based process of drilling is defined for each implant diameter. To control the tightening torque, there is an adjustable automatic torque wrench which bans the applied torque rising from the set amount. 
Since the risk number 33 is a surgeon-related risk factor, there is no systematic solution to reduce the probability of the occurrence. Therefore, the product design should result in primary stability which is higher than the typical required amount. On the other hand, microroughness of the surface improves the osseointegration rate. Thus, the severity of the hazardous situation is controlled to increase the relevant primary and secondary stability.

Based on the above results of Fig. 1, pre-mitigation and post-mitigation overall accumulated risk values, there is a relatively acceptable advancement on compensating the risks. All the identified risks factors are mitigated and moved to the acceptable and conditionally acceptable range. Figure 2 , is showing the difference on the RPN number before and after appropriate mitigations.

\section{Conclusion}

Through a complete risk management activity composed from risk analysis, risk evaluation, risk control, residual risk evaluation and production and post-production information this study has been performed. To complete the risk analysis, first of all, the identifiable risk factors (all the considered risk factors are directly or indirectly related to the final product quality) are gathered and listed. The risk value of each factor is then evaluated based on the severity and the frequency of occurrence on three categories, which are pictorially illustrated on Fig. 3.

The results of the residual risk factors after applying appropriate measurement are provided in Fig. 1 and Fig. 2. Different types of risks of the failure of the products, and also the procedures are included in this study. After applying the mitigations the residual risk of all the factors moved to the acceptable range or conditional acceptance range. At the end there is no risk on the non-acceptance region.

\section{Materials And Methods}

Based on the available standards for the risk classification of the medical devices, any risk at the application of the medical devices would be acceptable, conditionally acceptable or unacceptable. As defined in Fig. 1, there are 5 levels of severity including negligible, minor, serious, critical, and catastrophic which are rated from 1 to 5 based on their intensity [3]. In addition, the probability of occurrence of a hazardous situation has been classified. It is basically a continuous parameter, but in this case has dissected into 5 different levels including frequent, probable, occasional, remote, and improbable rated downward from 5 to 1 . The RPN factor is then calculated from the product of severity and probability as the accumulated risk factor.

After estimating the accumulated risk factors, risk versus benefit analysis is necessary. While dental implants restore the function of tooth's root or in some cases restore its anatomy [1], the benefits should outweigh the risks. In Table 1, the green blocks represent the risks areas with acceptable benefits. The yellow blocks represent the conditional acceptance of the product, where there should be adequate 
warnings supplied for the users from the manufacturer. The specific terms of use have to be clearly emphasized in the instructions for use to prevent foreseeable misuse.

In order to start the analysis, at the evaluation stage, all the risk factors with their foreseeable sequence of events and their severity level from the design stage to the long term application are assessed and listed. Through the assessment, the hazardous situations are evaluated and the harms are predicted.

After that the primary (proposed) solution to alleviate the concern (altering the risk) is provided. Thus, solutions for reducing the probability of occurrence or lowering the level of severity are investigated. In the results sections, the RPN is recalculated based on the new conditions, and the residual risks are measured to see whether they are acceptable or not. All the process of risk assessment of dental implants is graphically shown in Fig. 4.

There are several types of mitigations that have been proposed for currently considered risk factors. These mitigations are categorized based on their applications and the place they come to affect in the manufacturing process line:

Misuse preventive design,

Process control,

Three steps of quality control including initial (raw material) QC, in-line (semi-finished product) QC, and final product QC,

Information transfer assurance.

The mentioned items are the main topics for mitigations, and as you have seen in the above sections, the sub-categories are used in each case. In this research, risk analysis of the medical device has been studied according to the ISO 14971 medical device regulations. The international standard offers a variety of methods to find risks and analyze the risk factors. One of the most common methods is hazardous analysis and critical control points (HACCP). A simple method of evaluating risk factors based on their RPN number was used here. Then, three risk types are considered, however, the criteria were tighter than the sample provided in the standard.

\section{Declarations}

Ethics approval: Not Applicable.

Consent for publication: The authors are ready to sign any consent form or provide consent to publish sheet by their own format.

Availability of data and materials: Data and material are available upon request.

Competing interests: The authors declare that they have no significant competing financial or personal interests that might have influenced the performance of the worked described here. 
Funding: The authors would like to thanks the KFP-Dental implant manufacturing team to provide full technical and financial support to this research. Dental implant project is invested at KFP-Dental from late 2016.

Author's contribution: SAE has prepared the method and identified most of the risk factors. He has proposed the method and most of the mitigations. HR has proposed some of the mitigations, and also contributed in listing product related risks. HY reviewed the risks and added the process-based risks, prepared the results for the analysis and discussed them. Also he has worked on the background and finalized the work.

Acknowledgement: Every member of the implant manufacturing hall is involved in resolving risk factors and on the details of this research. Therefore, the authors are especially interested to give their thanks to Mahdi Galavi, Masoud Rezaei, Ehsan Gheibgholami, Sasan Sajedi and Dr Majid Rouhi Niasar.

\section{Author's information:}

Seyed Amirhossein Emamian Shirazi received his B.Sc. and M.Sc. in Biomedical Engineering from Amirkabir University of Technology in 2013 and 2016, respectively. Now, he has more than 6 years of professional working experiences in dental implant industry. He is currently doing a PhD of Biomechanics at Sahand University of Technology and cooperating with KoushaFanPars and Strauman at his dental implant research.

Hosseinali Ramazanpour received his B.Sc. in Biomedical Engineering from Amirkabir University of Technology in 2013 and his M.Sc. in Biomechanics from Iran Science and Technology, in 2016. Now, he has more than 7 years of professional working experience in manufacturing dental implant. He is currently the executive manager of the dental implant manufacturing line with KoushaFanPars and has a close collaboration with Strauman at his profession

Hashem Yousefi received his B.Sc. in Mechanical Engineering, at the University of Tehran, in 2004 and his M.Sc. e in Biomechanics from the Biomedical Engineering Department at Amirkabir University of Technology (Tehran Polytechnic), in 2011. He is submitted his PhD thesis to the board of the graduated studies in Auckland Bioengineering Institute at the University of Auckland. Currently, he is working professionally with KoushaFanPars.

\section{Abbreviations}

RPN Risk Priority Number

ERA Equivalent Risk Analysis

ISO International Standard Organization

QC Quality Control 
CNC Computer Numerical Control

HACCP Hazardous Situation \& Critical Control Point

\section{References}

1 - Vehemente, V. A., Chuang, S. K., Daher, S., Muftu, A., \& Dodson, T. B. (2002). Risk factors affecting dental implant survival. Journal of Oral Implantology, 28(2), 74-81.

2 - Chen, H., Liu, N., Xu, X., Qu, X., \& Lu, E. (2013). Smoking, radiotherapy, diabetes and osteoporosis as risk factors for dental implant failure: a meta-analysis. PloS one, 8(8), e71955.

3 - Braceras, I., Ipinazar, E., De Maeztu, M. A., \& Alava, J. I. (2008). Risk analysis and implants. Medical engineering \& physics, 30(9), 1201-1204.

4 - Mohanty, R., Sudan, P. S., Dharamsi, A. M., Mokashi, R., Misurya, A. L., \& Kaushal, P. (2018). Risk Assessment in Long-term Survival Rates of Dental Implants: A Prospective Clinical Study. The journal of contemporary dental practice, 19(5), 587-590.

5 - Schweitzer, K. M. (2002). Risk Factors in Implant Dentistry: Simplified Clinical Analysis for Predictable Treatment. Journal of Prosthodontics, 11(4), 326-327.

6 - Borba, M., Deluiz, D., Lurenco, E. J. V., Oliveira, L., \& Tannure, P. N. (2017), Risk factors for implant failure: a retrospective study in an educational institution using GEE analyses. Brazilian oral research, 31.

7 - Cosyn, J., De Bruyn, H., \& Cleymaet, R. (2013). Soft tissue preservation and pink aesthetics around single immediate implant restorations: A 1 year prospective study. Clinical implant dentistry and related research, 15(6), 847-857.

8 - Jackson, R. S., Price, D. L., Arce, K., \& Moore, E. J. (2016). Evaluation of clinical outcomes of osseointegrated dental implantation of fibula free flaps for mandibular reconstruction. JAMA facial plastic surgery, 18(3), 201-206.

9 - Liddelow, G., \& Klineberg, I. (2011). Patient-related risk factors for implant therapy. A critique of pertinent literature. Australian dental journal, 56(4), 417-426.

10 - De Araújo Nobre, M., Mano Azul, A., Rocha, E., \& Maló, P. (2015). Risk factors of peri-implant pathology. European journal of oral sciences, 123(3), 131-139.

11 - De Araújo Nobre, M., Salvado, F., Nogueira, P., Rocha, E., Ilg, P., \& Maló, P. (2019). A Peri-Implant Disease Risk Score for Patients with Dental Implants: Validation and the Influence of the Interval between Maintenance Appointments. Journal of clinical medicine, 8(2), 252.

\section{Figures}



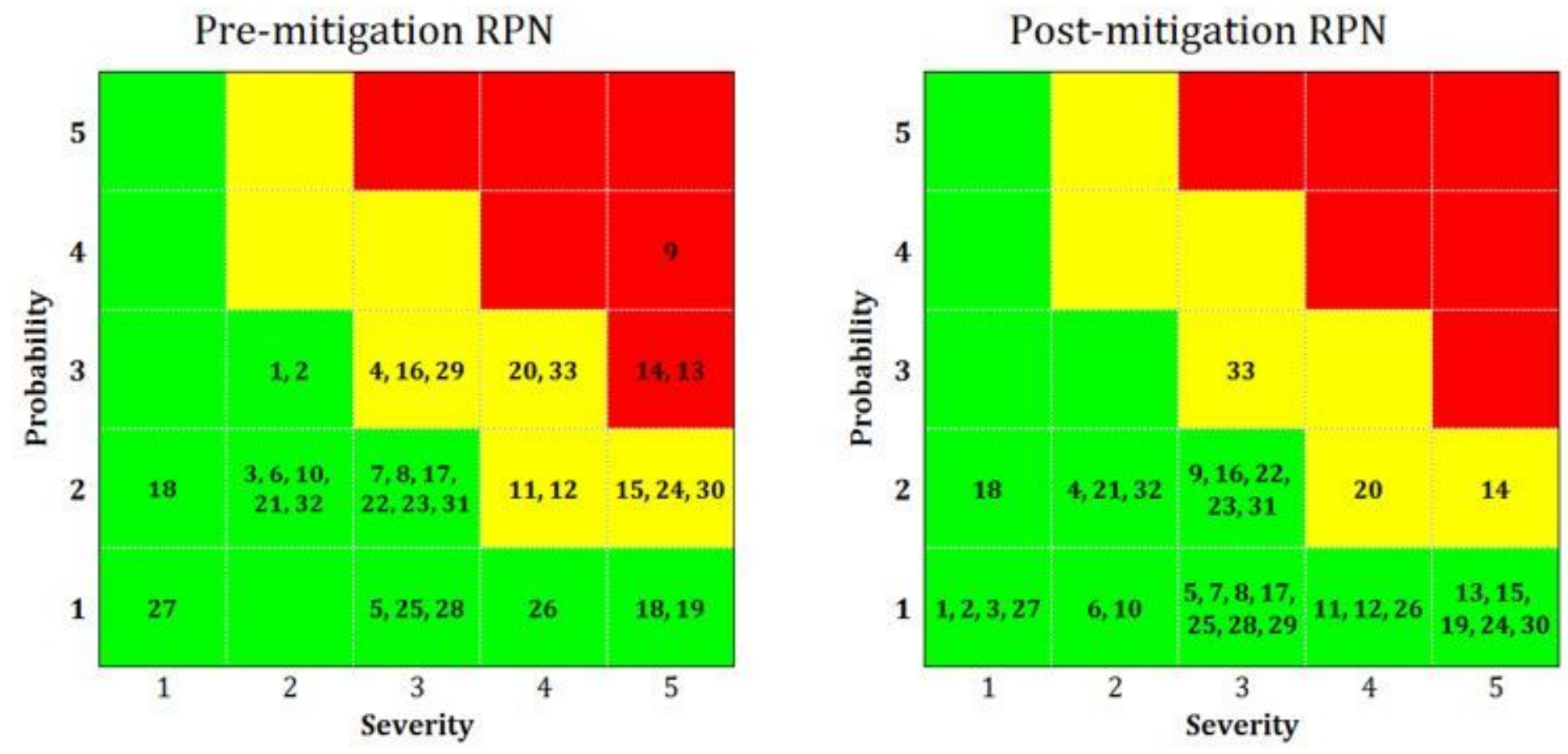

\section{Figure 1}

The RPN graph before and after applying mitigations.

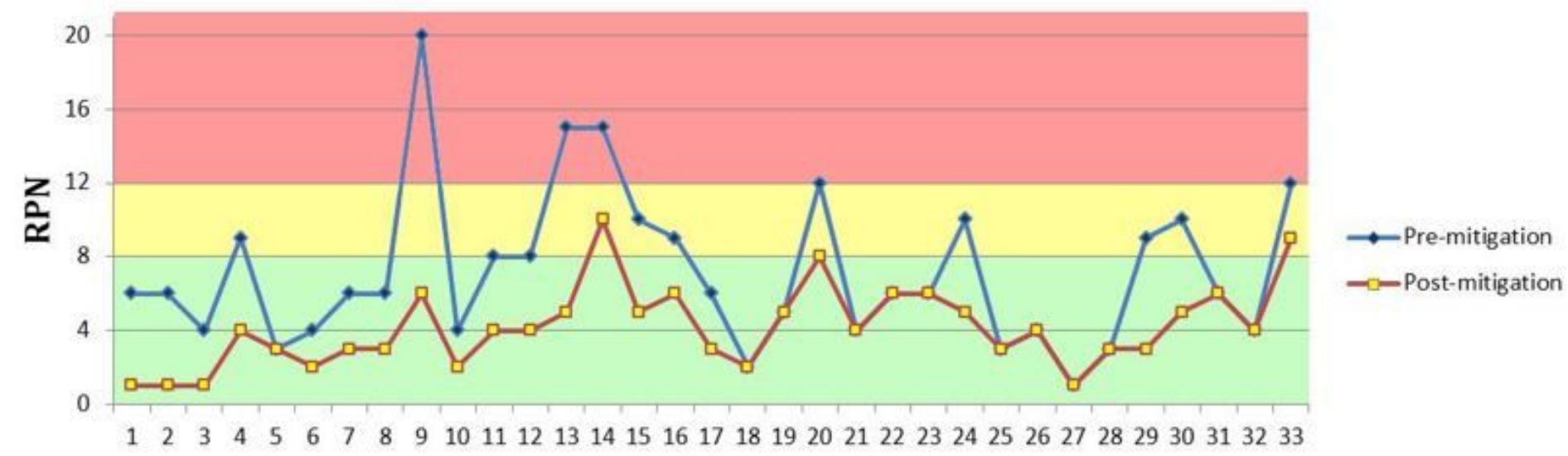

Risk factor

\section{Figure 2}

This figure shows the difference of RPN number for all the listed risk factors. The background red color shows the unacceptable criteria, the background yellow color shows the conditional acceptance margin and finally the risks in the green region are risks in the accepted region. 


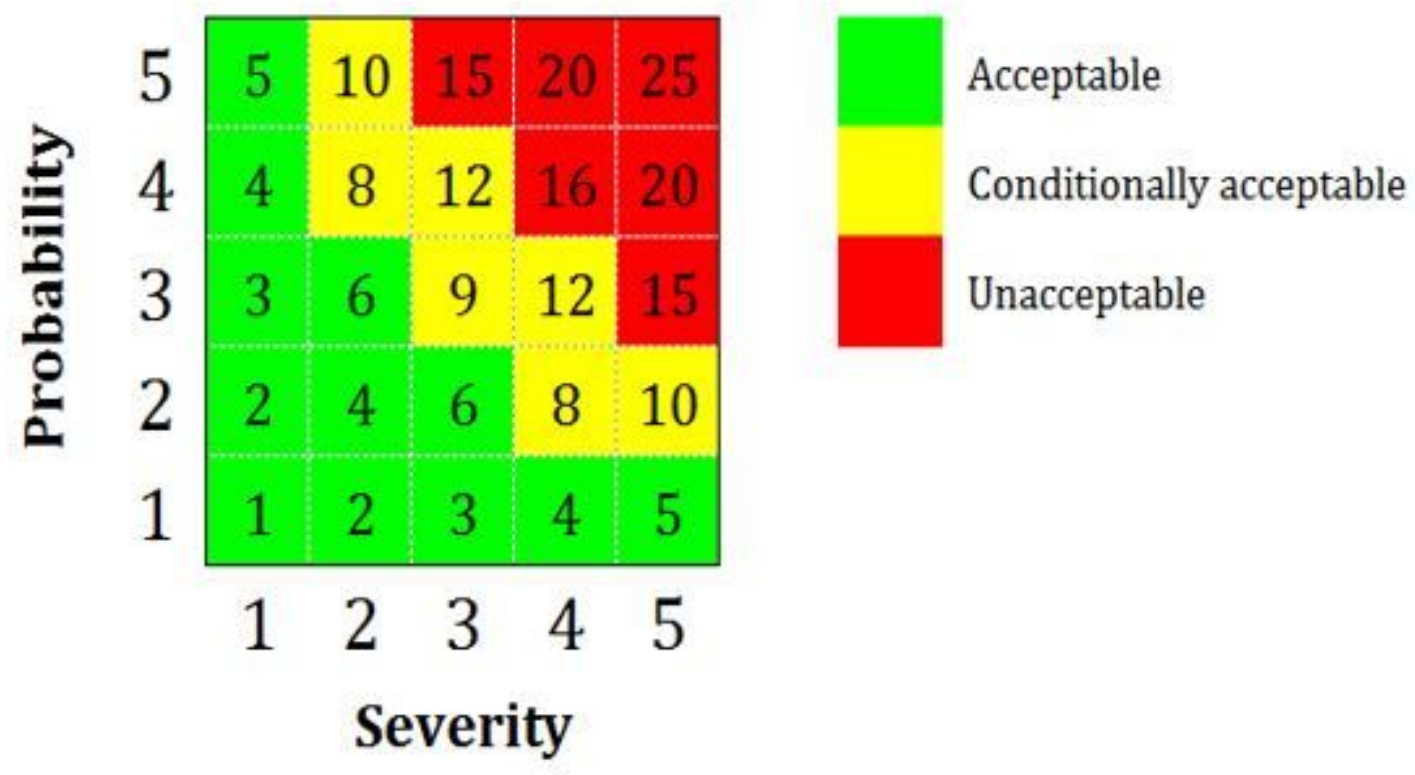

Figure 3

The figure shows the criteria for the accumulated risk factor. Three colors of green, yellow and red are symbols for the acceptance, conditionally acceptance and unacceptance of any specific risk for the product. 


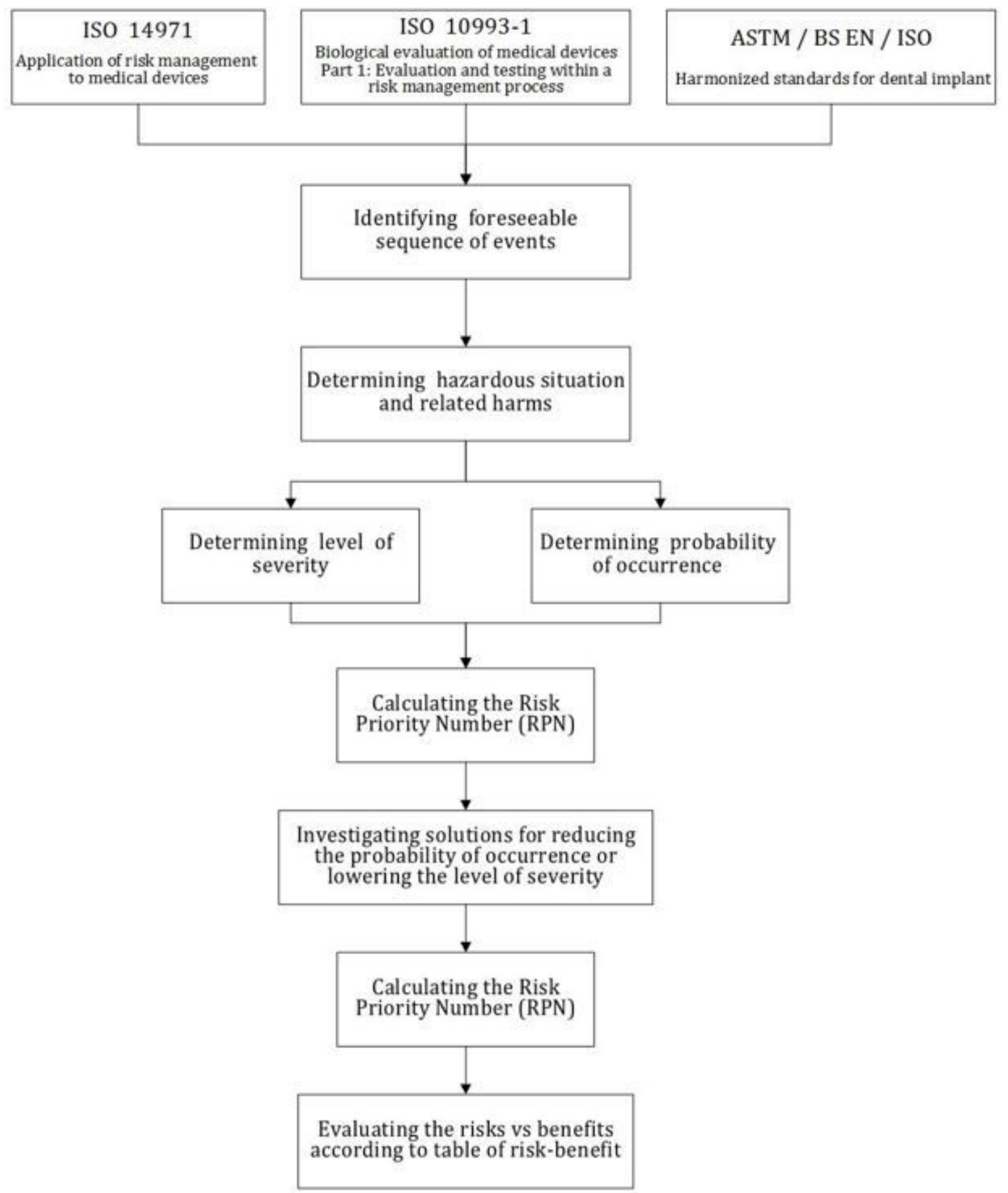

\section{Figure 4}

General structure of the risk management activity. 